\title{
Analysis of the tumor length and other prognosis factors in pT1-2 node-negative esophageal squamous cell carcinoma in a Chinese population
}

\author{
Zhengbo Song ${ }^{1,2}$, Jiwen Wang ${ }^{2,3}$, Baochai Lin ${ }^{1,2}$ and Yiping Zhang ${ }^{1,2^{*}}$
}

\begin{abstract}
Background: Tumor length is an important prognostic factor for many carcinomas, but its role in esophageal cancer remained undetermined. The aim of this study was to investigate the effect of tumor length on survival for patients with confined tumors (grade pT1-2) without lymph-node metastases in esophageal squamous cell carcinoma.

Methods: We enrolled 201 patients with esophageal squamous cell carcinoma (SCC) who had undergone surgical resection and been confirmed as pT1-2NOMO. The relationship of tumor length with overall survival was assessed and compared with other factors detailed in the American Joint Committee on Cancer (AJCC) tumor, node, metastasis (TNM) staging system published in 2009.

Results: The overall survival (OS) rates at 1,3, and 5 years were $93.0 \%, 83.7 \%$, and $69.2 \%$, respectively. The tumor length adversely affected OS, with the 5 -year rate being $93.5 \%, 82.0 \%, 68.6 \%, 67.9 \%, 55.3 \%$ and $41.1 \%$, respectively for tumor lengths of less than $10 \mathrm{~mm}, 10$ to $20 \mathrm{~mm}, 20$ to $30 \mathrm{~mm}, 30$ to $40 \mathrm{~mm}, 40$ to $50 \mathrm{~mm}$, and greater than $50 \mathrm{~mm}(P<0.001)$. Multivariate analyses showed that the pathologic $T$ classification and grade of tumor was significantly associated with OS. Tumor length of $30 \mathrm{~mm}$ or more remained an independent prognostic factor $(P=0.04)$, as did the other current TNM factors.
\end{abstract}

Conclusion: Tumor length appears to affect the OS of patients with early-stage esophageal squamous cell carcinoma. It may provide additional prognostic information for the current TNM staging system.

Keywords: Esophageal squamous cell carcinoma, TNM classification, Tumor length, Overall survival

\section{Background}

Before 1987, the American Joint Committee on Cancer (AJCC) staging system used tumor length to predict patient prognosis [1]; however, the current TNM staging system, first published in 2009, did not take tumor length into account [2]. In the current AJCC staging system for esophageal tumors, stage depends on the depth of the tumor ( $\mathrm{T}$ classification), lymph-node (LN) involvement ( $\mathrm{N}$ classification), and distant metastasis ( $\mathrm{M}$ classification).

\footnotetext{
* Correspondence: yipingzhang@yahoo.cn

'Department of Chemotherapy, Zhejiang Cancer Hospital, 38 Guangji Road, 310022 Hangzhou, People's Republic of China

${ }^{2}$ Key Laboratory Diagnosis and Treatment Technology on Thoracic Oncology, Zhejiang province, Hangzhou 310022, China

Full list of author information is available at the end of the article
}

Recent publications have suggested that pathologic esophageal tumor length is directly correlated with longterm survival [3-6]; however, most of these data originated in western countries, and the cancer type was predominantly adenocarcinoma.

The aim of this study is to evaluate the value of tumor length and other prognostic factors in predicting the behavior of early-stage esophageal squamous cell carcinoma (SCC) without LN involvement, and the outcome after definitive surgery for such cases, in a Chinese population.

\section{Methods}

We assessed patients who had undergone surgical resection for esophageal cancer between January 2002 and December 2008 in Zhejiang Cancer Hospital. The total

\section{Biomed Central}


number of patients was 1,325 , of whom 431 had received a pathological diagnosis of T1-2; 199 of these had LN metastasis, and were excluded. Of the 232 patients without LN metastasis, 13 did not have microscopically tumor-free margin (R0), and a further 18 either had fewer than 12 dissected LNs or had a cancer type other than SCC, and these were also excluded, leaving 201 patients for analysis.

All of the 201 patients with complete tumor resection had pathologically confirmed SCC. The tumor length was measured immediately after resection. Preoperative evaluation and staging investigations included a complete medical history and physical examination, complete blood count and serum biochemistry tests, and scans (for example, computed tomography (CT) of the thorax, ultrasonography of the upper abdomen, magnetic resonance imaging of the brain, total body bone scan, and fluorodeoxyglucosepositron emission tomography).

\section{Treatment}

The extent of the esophageal resection and LN dissection were decided at the time of the operation by the surgeons and took into account the general physical condition of the patient. None of the patients received adjuvant chemotherapy after surgery.

\section{Follow-up}

The surviving patients were followed up every 3 to 6 months for the first 5 years, then annually. Recording of medical history, physical examination, and CT of the chest were performed during the follow-up time. Endoscopic examination and whole-body examination were obtained in cases of clinically indicated recurrence or metastasis. Survival was measured from the date of surgery to the date of death or the final follow-up visit, with. June 2011 being the final censoring date for survival. The median time from surgery to the final censoring date was 52 months (range 30 to 136 months).

\section{Statistical analysis}

The Kaplan-Meier method was used to estimate survival curves. The definition of survival was determined from the date of surgery and the final known follow-up or the date of death. A univariate Cox proportional hazards regression model was used to examine the association between various prognostic predictors and survival. Possible prognostic factors associated with survival probability at a significance level of less than or equal to 0.20 were considered in a multivariable Cox proportional hazards regression analysis. $P<0.05$ was regarded as significant. All statistical tests were analyzed using SPSS software) version 16.0; SPSS Inc, Chicago, IL, USA).

\section{Results}

Patient characteristics

Table 1 shows the clinical characteristics of the 201 included patients. The population was predominantly male $(86.6 \%)$, with a median age of 59 years (range $31-$ 78 years). The most common tumor location was the middle and lower esophagus (94.1\%). Of the 201 patients, 115 patients had a tumor length of $30 \mathrm{~mm}$ or less and 86 patients had a tumor length greater than 30 $\mathrm{mm}$. The mean and median lengths of the esophageal tumors were 40 and $28 \mathrm{~mm}$, respectively. There were 168 patients who had undergone Ivor-Lewis esophageal resection, and these were categorized as one group for analysis, while patients who had undergone a triincisional esophageal resection $(n=25)$ or any other approach $(\mathrm{n}=8)$ were categorized together as another group. The mean number of LNs dissected was 24.9 (range 13 to 72 ).

Table 1 Demographic characteristics of the study population

\begin{tabular}{|c|c|}
\hline Variable & \\
\hline Gender, n (\%) & $201(100)$ \\
\hline Male & $174(86.6)$ \\
\hline Female & $27(13.4)$ \\
\hline \multicolumn{2}{|l|}{ Age, years } \\
\hline Range & 31 to 78 \\
\hline Median & 59 \\
\hline$<65, \mathrm{n}(\%)$ & $156(77.6)$ \\
\hline$\geq 65, n(\%)$ & $45(22.4)$ \\
\hline \multicolumn{2}{|l|}{ Pathologic T classification, n (\%) } \\
\hline $\mathrm{T1}$ & $91(45.3)$ \\
\hline T2 & $110(54.7)$ \\
\hline \multicolumn{2}{|l|}{ Grade, n (\%) } \\
\hline Well or moderately differentiated & $158(78.6)$ \\
\hline Poorly differentiated or undifferentiated & $43(21.4)$ \\
\hline \multicolumn{2}{|l|}{ Tumor length } \\
\hline Mean \pm SD & $4.0 \pm 2.5$ \\
\hline$\leq 30 \mathrm{~mm}, \mathrm{n}(\%)$ & $115(57.2)$ \\
\hline$>30$ mm, n (\%) & $86(42.8)$ \\
\hline \multicolumn{2}{|l|}{ Surgical procedure, n (\%) } \\
\hline Ivor-Lewis & $168(83.6)$ \\
\hline Tri-incisional & $25(12.4)$ \\
\hline Other & $8(4.0)$ \\
\hline \multicolumn{2}{|l|}{ Tumor location, n (\%) } \\
\hline Upper third & $12(5.9)$ \\
\hline Middle third & $102(50.7)$ \\
\hline Lower third & $87(43.4)$ \\
\hline \multicolumn{2}{|l|}{ No. of examined LNs, n (\%) } \\
\hline$<18$ & $29(14.4)$ \\
\hline$\geq 18$ & $172(85.6)$ \\
\hline
\end{tabular}




\section{Analysis by tumor length}

Survival time was assessed against increasing length of the tumor in $10-\mathrm{mm}$ increments. As previous reports reported that $30 \mathrm{~mm}$ was a well separation [3-6], we used this length to evaluate survival time.

There was a significant difference in survival between patients with tumors of $30 \mathrm{~mm}$ or less and patients with tumors greater than $30 \mathrm{~mm}(P=0.01)$ (Figure 1$)$. When survival was analyzed using size as a continuous variable, there was also a statistical association, with the 5-year survival rate being 93.5\%, 82.0\%, 68.6\%, 67.9\%, 55.3\%, and $41.1 \%$ for tumor lengths of less than $10 \mathrm{~mm}, 10$ to $20 \mathrm{~mm}, 20$ to $30 \mathrm{~mm}, 30$ to $4 \mathrm{~mm}, 40$ to $50 \mathrm{~mm}$, and more than $50 \mathrm{~mm}$, respectively $(P<0.001)$ (Figure 2). When survival was analyzed by tumor stage (T1 and $\mathrm{T} 2$ ), the length was also a significant prognostic factor $(P=0.04$ and $P=0.02$, respectively: Figure 3, Figure 4$)$. There was a significant difference in 5-year survival in T1a patients when sub-grouped as having tumors of $30 \mathrm{~mm}$ or less and tumors greater than $30 \mathrm{~mm}(91.0 \%$ versus $82.5 \%, P<0.05$;), and similar in T1b when subgrouped as having tumors of $30 \mathrm{~mm}$ or less and tumors greater than $30 \mathrm{~mm}(81.5 \%$ versus $72.2 \%, P<0.04)$. Similarly, the 5-year survival difference in T2a and T2b patients was also found when they were sub-grouped by tumor size with the cut-off of $30 \mathrm{~mm}$ (78.5\% versus $71.1 \%, P=0.04 ; 65.2 \%$ versus $57.2 \%, P=0.01)$.

\section{Factors affecting overall survival assessed by univariate and multivariate analysis}

Univariate analyses were performed using the KaplanMeier method to assess the predictive capability of each variable assessed (Table 2). As expected, pathologic $\mathrm{T}$ classification, tumor grade, and tumor length were predictive of survival. Age, gender, tumor location, surgical procedure, and number of examined LNs were not significantly associated with OS.

Variables used in the final model included age, gender, tumor location, pathologic $\mathrm{T}$ stage, surgical procedure, number of examined LNs and tumor length (Table 3). A multivariate Cox regression model was constructed to incorporate age, gender, histologic grade, and the tumor depth, location, and length $(30 \mathrm{~mm}$ or less versus more than $30 \mathrm{~mm}$ ). Tumor length $(30 \mathrm{~mm}$ or less versus more than $30 \mathrm{~mm}$ ), tumor depth, and histologic grade remained as independent prognostic factors (Table 3), but age, gender, and tumor location did not have a significant influence on survival in multivariate analysis.

\section{Discussion}

To our knowledge, this is one of the largest studies to evaluate the value of tumor length in predicting patient prognosis for resectable early-stage esophageal SCC. We found that pathologic esophageal tumor length was

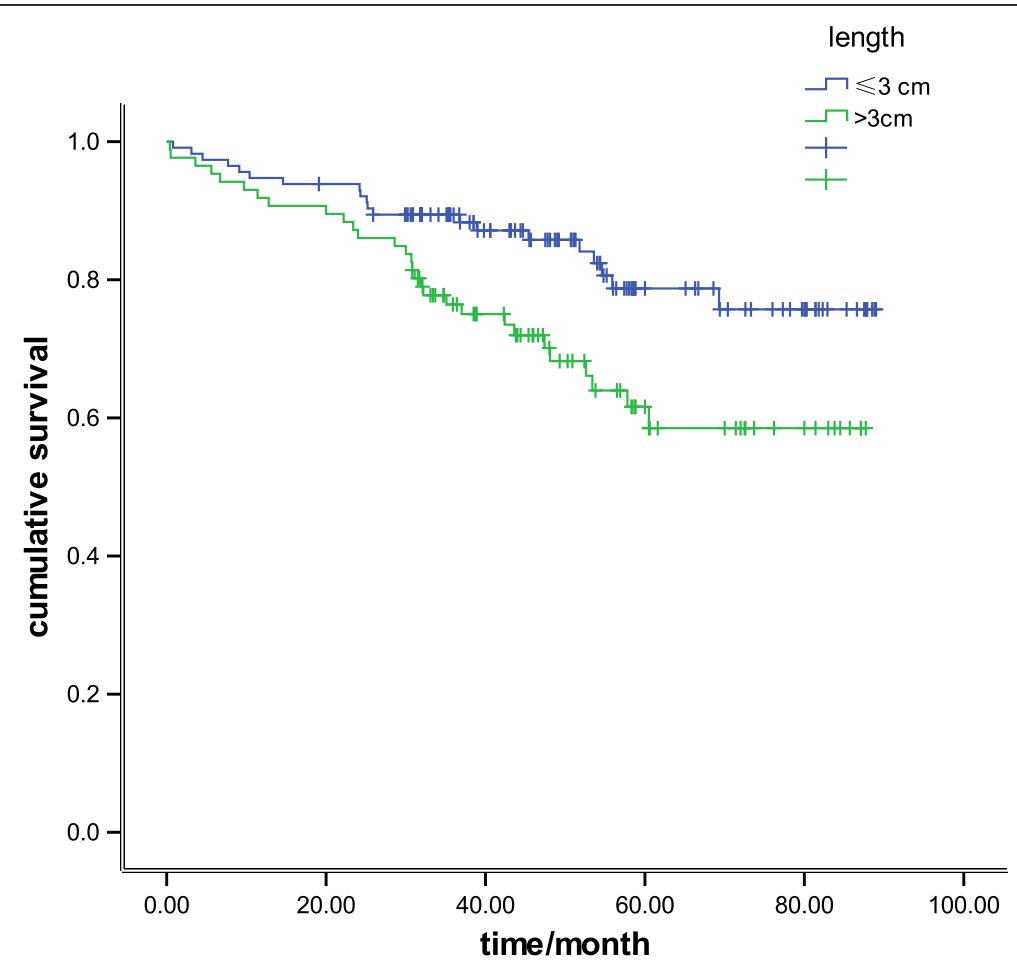

Figure 1 Kaplan-Meier survival curves in 201 patients with R0-resected esophageal carcinoma, comparing tumor length of $30 \mathrm{~mm}$ or less and greater than $30 \mathrm{~mm}(P=0.01)$. 


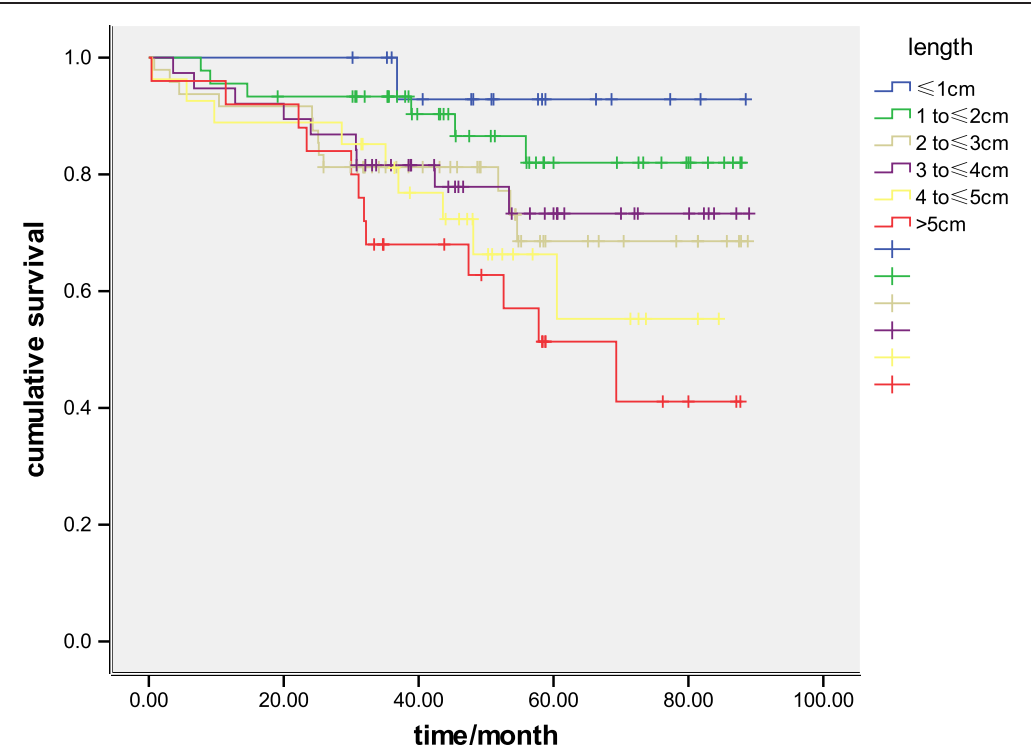

Figure 2 Kaplan-Meier survival curves in 201 patients with R0-resected early-stage esophageal carcinoma comparing tumor length in $10 \mathrm{~mm}$ increments $(P<0.001)$.

associated with long-term survival in esophageal SCC. Our results suggest that tumor length might be a valuable prognostic factor and might help to identify a highrisk group of patients after surgery for early-stage esophageal SCC.
According to the guidelines of the National Comprehensive Cancer Network, systemic chemotherapy is not recommended for esophageal carcinoma of pT1-2 without LN metastases; observation after complete tumor resection is the recommended approach. However, the

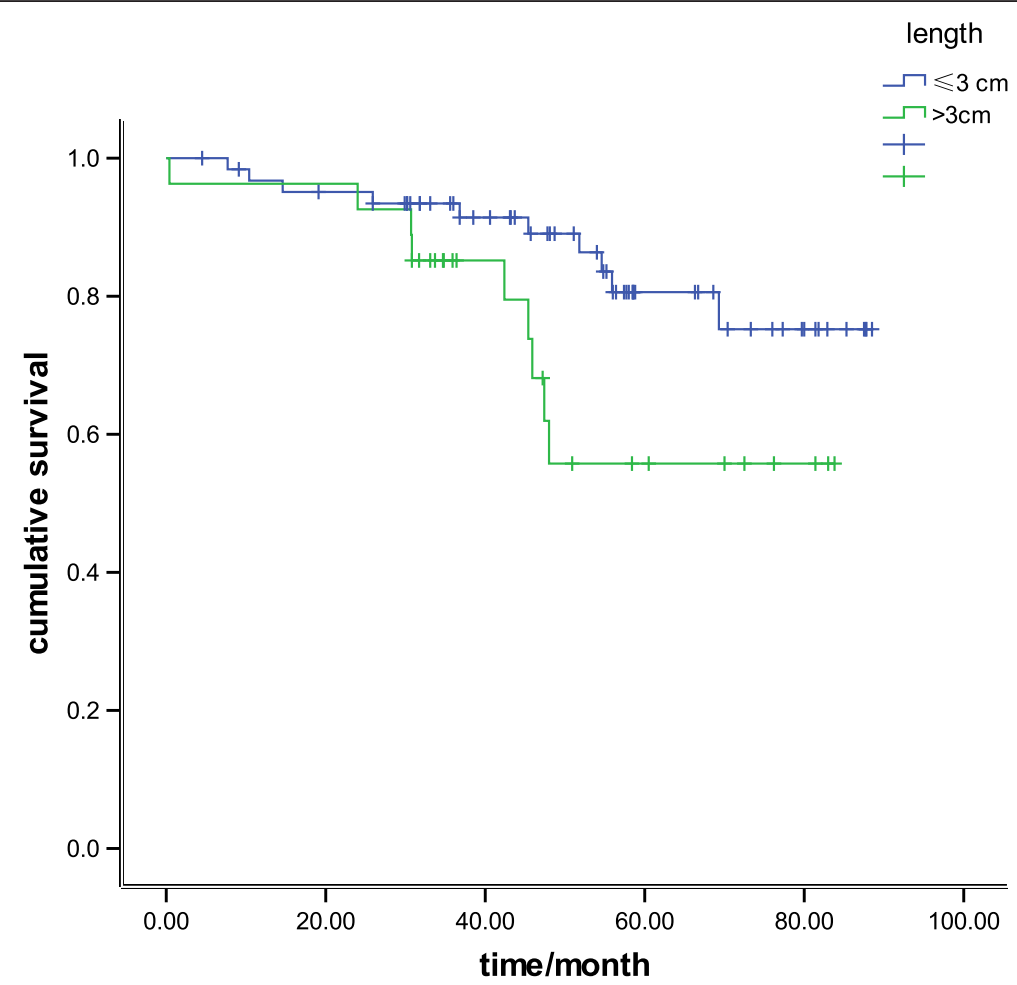

Figure 3 Kaplan-Meier survival curves in 91 patients assessed as pT1, comparing tumor length of $30 \mathrm{~mm}$ or less and greater than $30 \mathrm{~mm}(P=0.04)$. 


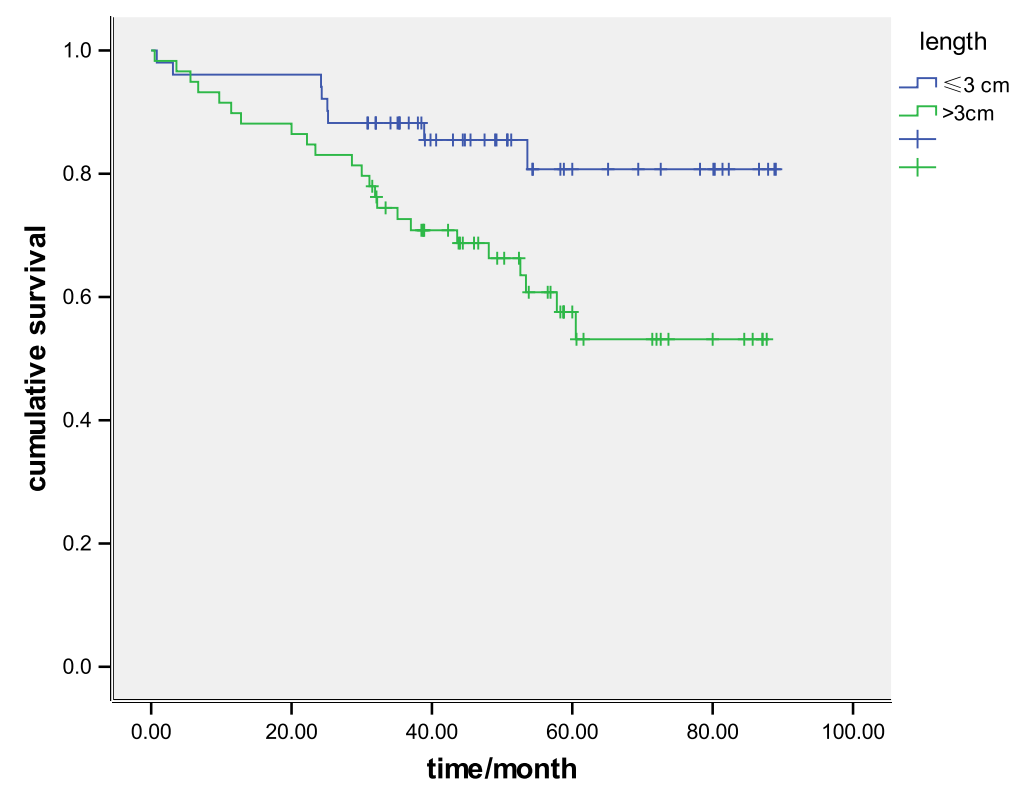

Figure 4 Kaplan-Meier survival curves in 110 patients assessed as pT2, comparing tumor length of $30 \mathrm{~mm}$ or less and greater than $30 \mathrm{~mm}(P=0.017)$.

5-year survival rate for some patients, thus it could be useful to assess possible risk factors in addition to tumor depth and grade. In other cancers, such as lung and breast cancers, tumor size is an important prognostic factor for predicting long-term survival, where as only tumor depth and grade are considered prognostic factors in the p-TNM staging for esophageal carcinoma [7]. Eloubeidi et al. [4] proposed a revised TNM classification for esophageal carcinoma to include tumor length. Other authors have also indicated the importance of tumor length for prognosis; however, most of these data were based on western populations, with the tumor type being predominantly adenocarcinoma [8-10].

In our study, we attempted to eliminate any influence of LN metastases by focusing only on the pathologic esophageal tumor length. In addition, we selected only patients who had undergone esophagectomy with complete tumor R0 resection achieved; any cases withoutR0 resection was excluded. Our study clearly demonstrates that tumor length is an independent predictor of long-term survival, and association of tumor length with survival was consistent regardless of whether length was analyzed as a continuous or categoric variable (Figure 1, Figure 2). In addition, this effect was present even when the other standard staging prognostic factors (pTNM) were taken into account.

The question of how many LNs should be dissected has been a point of debate in previous studies [11-13]. Greenstein et al. [14]. and Yang et al. [15] recommended 18 as the minimum number of resectable LNs, whereas Peyre et al. [16] recommended a minimum of 23 regional LNs, and Schwarz and Smith recommended at least 30 LNs be removed for an adequate lymphadenectomy [17]. However, most previous studies were included patients with locally advanced cancers. The LN dissection number was not clear in early-stage esophageal carcinoma. We did not find any survival difference when using $18 \mathrm{LNs}$ as a cut-off point in our data.

As noted by other authors, Tumor depth also correlated with long-term outcome in patients with different pT disease stages, as reported previously by other authors $[9,11]$. The overall 5-year survival rates for pT1 and $\mathrm{T} 2$ were $76.2 \%$ and $67.4 \%$, respectively in this study. Similarly, level of differentiation (well/moderately versus poorly/not) was also a strong prognosis factor in our study $(P=0.04)$.

Our study has several limitations. It was a retrospective study with all the limitations that accompany such a study. In addition, because the study used data from a single institution but with different pathologists and different surgeons, there may have been a lack of uniformity in measurement methods. The LN dissection number was also not consistent, and we also excluded patients who had a dissected LN number of less than 12, which may have influenced our analysis. Thus, carefully designed prospective studies are needed to confirm the role of tumor length in guiding esophageal SCC treatment.

\section{Conclusion}

In summary, our study suggests that esophageal tumor length in early-stage esophageal SCC without LN involvement could be a useful prognostic factor to help 
Table 2 Results of univariate analysis of the prognosis of 201 patients with esophageal carcinoma

\begin{tabular}{|c|c|c|c|c|}
\hline \multirow[t]{2}{*}{ Variable } & \multirow[t]{2}{*}{ Number } & \multicolumn{2}{|c|}{ Survival, $\%$} & \multirow{2}{*}{$\begin{array}{l}P \text { value } \\
\text { rs }\end{array}$} \\
\hline & & 3 years & 5 years & \\
\hline Gender & & & & 0.23 \\
\hline Male & 174 & 82.4 & 70.2 & \\
\hline Female & 27 & 92.6 & 77.8 & \\
\hline Age, years & & & & 0.94 \\
\hline$\geq 65$ & 45 & 77.2 & 74.2 & \\
\hline$<65$ & 156 & 85 & 67.6 & \\
\hline Surgical procedure & & & & 0.74 \\
\hline Ivor-Lewis & 168 & 83.6 & 73.5 & \\
\hline Tri-incisional & 25 & 83.8 & 65.5 & \\
\hline Other & 8 & 87.5 & 46.7 & \\
\hline Tumor grade & & & & 0.05 \\
\hline $\mathrm{T1}$ & 91 & 88.8 & 76.2 & \\
\hline $\mathrm{T} 2$ & 110 & 79.8 & 67.4 & \\
\hline Tumor length, mm & & & & 0.01 \\
\hline$>30$ & 86 & 89.5 & 78.9 & \\
\hline$\leq 30$ & 115 & 76.4 & 61.6 & \\
\hline \multicolumn{5}{|l|}{ Histologic grade } \\
\hline Well or moderately differentiated & 158 & 86.3 & 74.3 & 0.04 \\
\hline Poorly differentiated & 43 & 74.4 & 60.9 & \\
\hline Tumor location & & & & 0.68 \\
\hline Upper third & 12 & 83.3 & 55.6 & \\
\hline Middle third & 102 & 86 & 74.3 & \\
\hline Lower third & 87 & 81.4 & 70.1 & \\
\hline Lymph-node size, mm & & & & 0.33 \\
\hline$\geq 180$ & 172 & 84.6 & 72.9 & \\
\hline$<180$ & 29 & 79.2 & 62.3 & \\
\hline
\end{tabular}

identify high-risk patients with esophageal cancer before surgical resection. We found that esophageal tumor length was a significant independent predictor of longterm survival. We consider that it should be incorporated in the current esophageal cancer staging system to

Table 3 Terms included in the final multivariate model for the prediction of survival

\begin{tabular}{llll}
\hline Variable & $\begin{array}{l}\text { Hazard } \\
\text { ratio }\end{array}$ & $\begin{array}{l}\text { 95\% confidence } \\
\text { interval }\end{array}$ & P value \\
\hline Gender & 0.510 & 0.182 to 1.433 & 0.20 \\
\hline Age & 0.774 & 0.389 to 1.540 & 0.47 \\
\hline Surgical approach & 1.076 & 0.494 to 2.344 & 0.85 \\
\hline Tumor classification & 1.698 & 1.192 to 2.985 & 0.04 \\
\hline Tumor length & 2.161 & 1.178 to 3.965 & 0.04 \\
\hline Histologic grade & 2.016 & 1.081 to 3.763 & 0.03 \\
\hline Tumor location & 0.893 & 0.543 to 1.468 & 0.65 \\
\hline Number of examined LNs & 0.514 & 0.228 to 1.159 & 0.11 \\
\hline LN, lymph node. & & &
\end{tabular}

better predict the long-term survival of patients with esophageal cancer.

\section{Competing interests}

The authors declare that they have no competing interests.

\section{Authors' contributions}

YZ and ZS cooperated in the conception and design of the study, and in the collection of the data;JW and BL validated all pathology reports, and assisted in data analysis and interpretation of data; andZS drafted the manuscript. All authors approved the final manuscript.

\section{Author details}

${ }^{1}$ Department of Chemotherapy, Zhejiang Cancer Hospital, 38 Guangji Road, 310022 Hangzhou, People's Republic of China. ${ }^{2}$ Key Laboratory Diagnosis and Treatment Technology on Thoracic Oncology, Zhejiang province, Hangzhou 310022, China. ${ }^{3}$ Department of Thoracic Surgery, Zhejiang Cancer Hospital, Hangzhou 310022, China.

Received: 22 July 2012 Accepted: 24 November 2012 Published: 18 December 2012

\section{References}

1. American Joint Committee on Cancer: In Manual for Staging of Cancer. 2nd edition. Edited by Beahrs $\mathrm{OH}$, Myers MH. Philadelphia, PA: JB Lippincott; 1983.

2. Edge SB, Byrd DR, Compton CC, et al: American Joint Committee on Cancer (AJCC) Cancer Staging Manual. Chicago: Springer, Inc; 2010.

3. Gaur P, Sepesi B, Hofstetter WL, Correa AM, Bhutani MS, Watson TJ, Swisher SG: Endoscopic esophageal tumor length-a prognostic factor for patients with esophageal cancer. Cancer 2011, 117:63-69.

4. Eloubeidi MA, Desmond R, Arguedas MR, Reed CE, Wilcox CM: Prognostic factors for the survival of patients with esophageal carcinoma in the $\mathrm{U}$. S.: the importance of tumor length and lymph node status. Cancer 2002, 95:1434-1443.

5. Griffiths EA, Brummell Z, Gorthi G, Pritchard SA, Welch IM: Tumor length as a prognostic factor in esophageal malignancy: univariate and multivariate survival analyses. J SurgOncol 2006, 93:258-267.

6. Bolton WD, Hofstetter WL, Francis AM, Correa AM, Ajani JA, Bhutani MS, Erasmus J, Komaki R, Maru DM, Mehran RJ, Rice DC, Roth JA, Vaporciyan AA, Walsh GL, Swisher SG: Impact of tumor length on long-term survival of pT1 esophageal adenocarcinoma. J ThoracCardiovascSurg 2009, 138:831-836.

7. Rice TW, Rusch WW, Blackstone EH: AJCC/UICC staging of esophageal cancer. In General Thoracic Surgery. 7th edition,Vol 2. Edited by Shields TW, Locicero J, Reed CE, Feins RH. Amsterdam, Netherlands: Wolters, Kluwer; 2009:2013-2015

8. Davies L, Mason JD, Roberts SA, Chan D, Reid TD, Robinson M, Gwynne S, Crosby TD, Lewis WG: Prognostic significance of total disease length in esophageal cancer. Surg Endosc 2012, 26:2810-2816.

9. Bollschweiler E, Baldus SE, Schröder W, Schneider PM, Hölscher H: Staging of esophageal carcinoma: length of tumor and number of involved regional lymph nodes. Are these independent prognostic factors? J SurgOncol 2006, 94:355-363.

10. Wang BY, Goan YG, Hsu PK, Hsu WH, Wu YC: Tumor Length as a prognostic factor in esophageal squamous cell carcinoma. Ann ThoracSurg 2011, 91:887-893.

11. Mariette C, Piessen G, Briez N, Triboulet JP: The number of metastatic lymph nodes and the ratio between metastatic and examined lymph nodes are independent prognostic factors in esophageal cancer regardless of neoadjuvantchemoradiation or lymphadenectomy extent. Ann Surg 2008, 247:365-371.

12. Altorki NK, Zhou XK, Stiles B, Port JL, Paul S, Lee PC, Mazumdar M: Total number of resected lymph nodes predicts survival in esophageal cancer. Ann Surg 2008, 248:221-226.

13. Roder JD, Busch R, Stein HJ, Fink U, Siewert JR: Ratio of invaded to removed lymph nodes as a predictor of survival in squamous cell carcinoma of the oesophagus. Br J Surg 1994, 81:410-413.

14. Greenstein AJ, Litle VR, Swanson SJ, Divino CM, Packer S, Wisnivesky JP: Effect of the number of lymph nodes sampled on postoperative survival of lymph node-negative esophageal cancer. Cancer 2008, 112:1239-1246. 
15. Yang $H X, X u Y, F u J H$, Wang JY, Lin $P$, Rong TH: An evaluation of the number of lymph nodes examined and survival for node-negative esophageal carcinoma:data from China. Ann SurgOncol 2010, 17:1901-1911.

16. Peyre CG, Hagen JA, DeMeester SR, Altorki NK, Ancona E, Griffin SM, Hölscher A, Lerut T, Law S, Rice TW, Ruol A, van Lanschot JJ, Wong J, DeMeester TR: The number of lymph nodes removed predicts survival in esophageal cancer: an international study on the impact of extent of surgical resection. Ann Surg 2008, 248:549-556.

17. Schwarz RE, Smith DD: Clinical impact of lymphadenectomy extent in resectable esophageal cancer. J GastrointestSurg 2007, 11:1384.

doi:10.1186/1477-7819-10-273

Cite this article as: Song et al:: Analysis of the tumor length and other prognosis factors in pT1-2 node-negative esophageal squamous cell carcinoma in a Chinese population. World Journal of Surgical Oncology 2012 10:273.

\section{Submit your next manuscript to BioMed Central and take full advantage of:}

- Convenient online submission

- Thorough peer review

- No space constraints or color figure charges

- Immediate publication on acceptance

- Inclusion in PubMed, CAS, Scopus and Google Scholar

- Research which is freely available for redistribution 